Nama: Rismawati

Nim: 90100118032

Kelas ekonomi islam A

\title{
SEJARAH PEMIKIRAN EKONOMI ISLAM PADA MASA NABI
}

Kontribusi kaum muslimin yang sangat besar terhadap kelangsungan dan perkembangan pemikiran ekonomi pada peradaban dunia, setelah di abadikan oleh ilmuan Barat. Buku-buku teks ekonomi Barat hampir tidak pernah menyebutkan peranan kaum muslimin. Berbagai praktik dan kebijakan ekonomi yang berlangsung pada masa Rasulullah Saw merupakan contoh empirik yang dijadikan pijak bagi para cendikiawan muslim dalam melahirkan tero ekonomi. Satu hal yang jelas focus perhatian mereka tertuju pada pemenuhan kebutuhan, keadilan, efisiensi, pertumbuhan dan kebebasan yang tidak lain merupakan objek utama yang menginspirasikan pemikiran ekonomi islam sejak masa awal. Berkenaan dengan hal tersebut siddiqi memguraikan sejarah ekonomi islam dalam tiga fase yaitu sebagai berikut:

a. Fase pertama

Fase pertama merupakan fase abad awal sampai dengan abad ke-5 Hijriyah atau abad ke-11 Masehi yang dikenal sebagai fse dasar-dasar ekonomi islam yang dirintis oleh para fukaha, diikuti oleh sufi dan kemudian oleh filosof.

b. Fase kedua

Fase kedua yang dimulai pada abad ke-11 sampai dengan abad ke-15 Masehi dikenal sebagai fase yang cemerlang karena meninggalkan warisan intelektual yanga sangat kaya. 
c. Fase ketiga Fase ketiga dimulai pada tahun 1446 hingga 1932 Masehi merupakan fase tertutupnya pintu ijtihad (independent judgement) yang mengakibatkan fase ini dikenal juga sebagai fase stagnasi. ${ }^{1}$

Islam mempunyai pandangan yang jelas mengenai harta dan kegiatan ekonominya sebagaimana telah dicontohkan oleh teladan kita Muhammad. Rasulullah Saw beberapa pemikiran ekonomi islam yang disadur ilmuan Barat antara lain, teori invisible hands yang berasal dari Nani SAW dan sangat populer dikalangan ulama. Teoeri ini berasal dari Nabi SAW. ${ }^{2}$

Islam menempatkan pasar pada kedudukan yang penting dalam perekonomian. Praktik ekonomi pada masa Rasulullah dan khulafaurrasyidin menunjukkan adanya peranan pasar yang besar. Rasulullah Saw sangat menghargai harga yang dibentuk oleh pasar sebagai harga yang adil. Beliau menolak adanya prive intervention seandainya perubahan harga terjadi karena menaknisme pasar yang wajar, namun pasar mengharuskan adanya moralitas (fairplay), kejujuran (honesty), keterbukaan (transparansi), dan keadilan (justice). Jika nilai-nilai ini ditegakkan maka tidak ada alasan untuk menolah harga pasar. ${ }^{3}$

\section{DAFTAR PUSTAKA}

Kamiruddin, parakkasi idris h.2018. "analisis harga dan mekanisme pasar dalam perspektif islam” jurnal Laa Maysir, volume 5 No. 1 hlm 112

Fauzan, ibnudin. 2019. "the the thingking islamic economy in Muhammad prophet era (pemikiran ekonomi islam pada masa Nabi Muhammad)"risalah jurnal pendidikan dan studi islam 5,1 march 54

Siti aminah caniago, zaqirotul maghfiroh.2020. "pemikiran ekonomi islam pada masa peradaban Rasulullah SAW." Wacana equilibrium (jurnal pemikiran penelitian ekonomi), 8.2 115-116

\footnotetext{
${ }^{1} \mathrm{H}$. idris parakkasi, kamiruddin." analisis harga dan mekanisme pasar dalam perspektif islam". Jurnal Laa Maysir, volume 5 No. 12018 hlm 112

${ }^{2}$ Ibnudin, fauzan. "the the thingking of Islamic economy in muhammad prophet era (pemikiran ekonomi islam pada masa Nabi Muhammad)" Risalah jurnal pendidikan dan studi islam, 5, 1, march (2019): 54

${ }^{3}$ Magfiroh, zaqirotul, and siti aminah caniago." pemikiran ekonomi islam pada masa peradaban Rasulullah SAW." Wacana equilibrium (jurnal pemikiran penelitian ekonomi), 8.2 (2020) 115-116
} 
